\title{
Pengaruh Leverage,Ukuran Perusahaan,Intentitas Modal, Debt Covenant, Dan Profitabilitas Terhadap Konservatisme Akutansi
}

\author{
Anggi Sapitri ${ }^{1}$, Mohamad Zulman Hakim², Dirvi Surya Abbas ${ }^{3}$ \\ Universitas Muhammadiyah Tangerang ${ }^{1,2,3}$ \\ Koresponden Email : anggisapitri356@gmail.com
}

\begin{abstract}
Abstrak: Tujuan penelitian ini adalah menganalisis: Pengaruh leverage, ukuran perusahaan, intentitas modal, debt covenant, dan profitabilitas terhadap konservatisme akutansi. Populasi yang diteliti yaitu perusahaan sektor infrastructure, utilities, dan transportasi yang terdaftar di Bursa Efek Indonesia (BEI) Periode 2017-2018. Teknik pengambilan sampel menggunakan teknik sampling dan diperoleh sampel sebanyak 15 perusahaan dengan 2 tahun pengamatan. Penelitian ini menggunakan metode observasi non partisipan yang diambil dari data laporan tahunan dan laporan keuangan perusahaan. Teknik analisis yang digunakan adalah regresi data panel dengan program EViews 9. Hasil penelitian ini yaitu: Leverage, intentitas Modal, dan Profitabilitas terbukti tidak berpengaruh terhadap Konservatisme akutansi. Debt Covenant terbukti berpengaruh negative terhadap Konservatisme akutansi. Ukuran perusahaan terbukti berpengaruh positive terhadap Konservatisme Akutansi.
\end{abstract}

Kata kunci: Leverage; ukuran perusahaan; intentitas modal; debt covenant; profitabilitas; konservatisme akutansi.

Konservatisme sebagai prinsip kehati- hatian dalam pelaporan keuangan dimana perusahaan tidak terburu-buru dalam mengakui dan mengukur aktiva dan laba serta segera mengakui kerugian dan hutang yang mempunyai kemungkinan yang terjadi Watts (2003). Penerapan prinsip ini mengakibatkan pilihan metode akuntansi ditujukan pada metode yang melaporkan laba atau aktiva yang lebih rendah serta melaporkan hutang lebih tinggi.

Laporan keuangan PT Garuda Indonesia Tbk (GIAA) 2018 sedang jadi sorotan. Perolehan laba bersih perusahaan dianggap janggal. Pada 2018 GIAA mencatatkan laba bersih Rp 11,33 miliar. Laba itu berkat melambungnya pendapatan usaha lainnya yang totalnya mencapai US\$ 306,88 juta.

Ada dua komisaris yang enggan menandatangani laporan keuangan itu. Mereka merasa keberatan dengan pengakuan pendapatan atas transaksi Penerbangan, antara PT Mahata Aero dan PT Citilink Indonesia. Pengakuan itu dianggap tidak sesuai dengan kaidah Pernyataan Standar Akuntansi Keuangan (PSAK) nomor 23.

Manajemen Garuda Indonesia

mengakui pendapatan dari Mahata sebesar US\$239.940.000, yang diantaranya sebesar US\$28.000.000 merupakan bagian dari bagi hasil yang didapat dari PT Sriwijaya Air. Padahal uang itu masih dalam bentuk piutang, namun diakui perusahaan masuk dalam pendapatan.

Namun pemegang saham terbesar yakni Pemerintah berpandangan sebaliknya. https://finance.detik.com/. Leverage merupakan rasio yang menunjukkan seberapa besar hutang 
atau modal membiayai aktiva perusahaan Berdasarkan teori agensi, terdapat hubungan keagenan antara manajer dan kreditor. Manajer yang ingin mendapatkan kredit akan mempertimbakan rasio leverage (Dyahayu, 2012). Hasil penelitian

Sari dan Adhariani, (2009) menunjukkan bahwa rasio leverage yang semakin besar akan cenderung mendorong perusahaan mengatur laba dan menyajikan laporan keuangan yang cenderung tidak konservatif.. menurut (suharni, dkk,2018) Leverage tidak berpengaruh terhadap Konservatisme. Sedangkan menurut (Dewi dan Suryanawa 2014) Leverage mempunyai pengaruh yang positif dan signifikan pada penerapan konservatisme akuntansi. Dan menurut (Noviantari dan Dwi Ratnadi 2015) Leverage berpengaruh negatif pada konservatisme akuntansi.

Ukuran Perusahaan Menurut Purnama dan Daljono (2013) menyatakan bahwa ukuran perusahan secara umum dapat diartikan sebagai suatu perbandingan besar atau kecilnya suatu objek. Menurut (Susanto dan Ramadhani 2016) Ukuran perusahaan tidak berpengaruh terhadap konservatisme. Sedangkan Menurut (Daljono 2013) ukuran perusahaan berpengaruh positif terhadap konservatisme dan menurut (Ramadhani dan Sulistyowati 2019) ukuran perusahaan berpengaruh negatif.

Financial distress dapat mendorong pemegang saham untuk mengganti manajer perusahaan karena manajer dianggap tidak mampu mengelola perusahaan dengan baik. Hal tersebut akan dapat mendorong manajer untuk merubah laba yang menjadi salah satu tolak ukur kinerja manajer dengan jalan mengatur tingkat konservatisme akuntansi. Apabila suatu perusahaan tidak memiliki masalah keuangan, manajer tidak akan menghadapi tekanan pelanggaran kontrak. Sehingga financial distress yang semakin tinggi akan mendorong manajer untuk menyajikan laporan keuangan yang tidak konservatif (Lo, 2005). Menurut (Noviantari dan Dwi Ratnadi 2015) Financial distress berpengaruh negatif pada konservatisme akuntansi. Sedangkan Menurut Setiyaning dan Nuraina 2013) Financial distress tidak berpengaruh terhadap konservatisme akutansi.Dan menurut (Zuhriyah 2015) Financial distress berpengaruh positf terhadap konservatisme akutansi.

Debt covenant adalah kontrak hutang yang ditujukan pada peminjam oleh kreditur dengan tujuan untuk mendapatkan pinjaman dana yang disertai perjanjian-perjanjian yang telah disepakati dalam pengembalian pinjaman tersebut. Sebagian kesepakatan hutang berisi perjanjian (covenant) yang mengharuskan peminjam memenuhi. syarat yang disepakati dalam perjanjian hutang (Scott, 2000). Watts dan Zimerman (1986) mengidentifikasikan perjanjian seperti pembatasan dividen dan pembatasan pembelian kembali saham, pembatasan modal kerja, pembatasan merger, pembatasan akuisisi, pembatasan investasi, pembatasan pelepasan asset, pembatasan pembiayaan masa depan merupakan bentuk debt covenant.Menurut (Iskandar dan Sparta 2016) 
debt covenant berpengaruh negatif terhadap konservatisme akutansi.Dan Menurut (Sari dkk, 2013) debt covenant berpengaruh positif terhadap konservatisme akutansi. Sedangkan Menurut (Savitri 2016) debt covenant tidak berpengaruh terhadap konservatisme akutansi.

Profitabilitas merupakan kemampuan perusahaan didalam menghasilkan laba. Profitabilitas mencerminkan keuntungan dari investasi keuangan. Profitability ratio merupakan rasio untuk mengukur kemampuan perusahaan memperoleh laba dalam hubungannya dengan penjualan, total aktiva maupun modal sendiri (Sartono, .2010). Menurut (Susilo dan Aghni 2014) profitabilitas berpengaruh positif signifikan terhadap konservatisme akuntansi.Sedangkan Menurut (Utama dan Titik 2018) profitabilitas berpengaruh negatif terhadap konservatisme akuntansi. Dan Menurut (Surya 2015) profitabilitas tidak berpengaruh.

Profitabilitas perusahaan merupakan salah satu dasar penilaian kondisi suatu perusahaan terutama untuk menganalisis kinerja manajemen. Semakin tinggi tingkat profitabilitas suatu perusahaan, maka akan cenderung memilih akuntansi yang konservatif..Perusahaan dengan

profitabilitas tinggi akan cenderung menggunakan akuntansi yang konservatif untuk melakukan manajemen laba agar laba tidak begitu mengalami fluktuasi.

\section{METODE}

Penelitian ini merupakan penelitian kuantitatif dengan menggunakan regresi linier berganda dengan data penelitian menggunakan data sekunder. Data sekunder dalam penelitian ini adalah laporan keuangan tahunan perusahaan sektor Infrastructure,Utilities and Transportation yang terdapat di Bursa Efek Indonesia (BEI) dari tahun 2017 dan tahun 2018. Pengambilan sampel dengan menggunakan purposive sampling dengan kriteria perusahaan yang menerbitkan laporan keuangan auditan tahun 2017 - 2018, perusahaan yang menyajikan laporan keuangan dalam mata uang rupiah dan memiliki data yang lengkap terkait dengan variabelvariabel yang digunakan dalam penelitian.Populasi penelitian ini adalah seluruh perusahaan yang terdaftar di Bursa Efek Indonesia dengan sampel perusahaan pada sektor aneka industry. Teknik pengambilan sampel menggunakan metode purposive sampling, dengan data perusahaan yang memiliki kriteria sebagai berikut:

Tabel 2. Kriteria sample data

Keterangan

Perusahaan Sektor Aneka Industri yang 44 listing di BEl tahun 2016-2019

Perusahaan yang tidak melaporkan Laporan

Keuangan selama periode 2016 - 2019

Tahun pengamatan 2016 - $2019 \quad 8$

Jumlah observasi total periode penelitian (8 32

$\mathrm{X} 4)$ 
Konservatisme Akuntansi ( $Y$ )

Konservatisme Akuntansi, yang merupakan sebuah prinsip perusahaan berhati-hati dalam menentukan setiap nilai yang ada dilaporan keuangan, sehingga nilai yang ada di pos-pos keuangan memiliki nilai yang bisa dipertanggungjawabkan. Konservatisme dalam penelitian ini diukur dengan menggunakan market to book (Agustina et al.,2015), yaitu:

Market to Book= $\frac{\text { Harga pasar per saham }}{\text { Nilai Buku per saham }}$

$$
\text { Nilai Buku per Saham }=\frac{\text { Total Ekuitas }}{\text { Jumlah saham Beredar }}
$$

Leverage (X1)

Leverage merupakan rasio yang menunjukkan seberapa besar utang atau modal membiayai aktiva perusahaan (Noviantari dan Ratnadi, 2015). Leverage dihitung dengan melihat proposi besarnya aset yang dibiayai oleh hutang.

\section{Leverage $=($ Total Hutang $) /($ Total Modal $)$}

\section{Ukuran Perusahaan (X2)}

Ukuran perusahaan merupakan ukuran yang digunakan untuk mengukur perusahaan dari seberapa luas pengungkapan informasi. Penelitian ini menggunakan pengukuran perusahaan dengan rumus sebagai berikut:

$$
\text { Size = Log Natural }(\text { Total Aset })
$$

Intenstitas Modal (X3)

Intensitas modal merupakan besaran modal berupa aset yang dimiliki dan dibutuhkan oleh entitas untuk menghasilkan pendapatan.

\section{Debt Covenant (X4)}

$$
\text { IM =Total Asset /Penjualan }
$$

Debt Covenant adalah kontrak hutang yang bertujuan menganalisis pembelanjaan yang dilakukan perusahaan untuk melunasi utang serta kemampuan perusahaan membayar bunga dan beban. Pengukuran debt covenant dapat dirumuskan sebagai berikut:

Profitabilitas (X5)

$$
\text { DC = (Total Hutang }) /(\text { Total Aset })
$$

Profitabilitas adalah kemampuan perusahaan dalam menghasilkan laba melalui semua kemampuan dan sumber daya yang ada. Pada penelitian ini profitabilitas diproksikan dengan Return On Asset (ROA). ROA dapat dihitung menggunakan (Brigham, 2006):

$$
\text { ROA }=\frac{\text { Laba Bersih }}{\text { Total Aktiva }} \times 100 \%
$$


Dalam penelitian ini, teknik analisis data yang digunakan adalah analisis regresi data panel dengan bantuan sofware pengolah data statistik yaitu Eviews 9.0. Adapun metode analisis data yang digunakan dalam penelitian ini terdiri dari:

1. Analisis Statistik Deskriptif

Statistik deskriptif biasanya digunakan oleh peneliti untuk memberikan informasi mengenai karakteristik variabel penelitian yang utama (Alpiah, 2018). Deskripsi data statistik terdiri dari mean, median, maximum, minimum, standard deviation, skewness, kurtosis, Jarque-Bera, dan probability (Winarno, 2015).

2. Estimasi Regresi Data Panel Model Regresi Data Panel terbagi menjadi 3 model yaitu common effects, fixed effects, dan random effects.

3. Teknik Pemilihan Model Regresi Data Panel

Teknik Pemilihan Model Regresi Data Panel terbagi menjadi 3 model yaitu uji chow, uji hausman, dan uji lagrange multiplier.

a. Uji Chow

Hipotesis dalam Chow Test adalah sebagai berikut:

$\mathrm{HO}$ : Model mengikuti common effect

$\mathrm{Ha}$ : Model mengikuti fixed effect

b. Uji Hausman

Hipotesis dalam Hausman test adalah sebagai berikut:

$\mathrm{HO}$ : Model mengikuti random effect

$\mathrm{Ha}$ : Model mengikuti fixed effect

c. Uji Lagrange Multiplier

Hipotesis dalam Lagrange Multiplier test adalah sebagai berikut:

$\mathrm{HO}$ : Model mengikuti common effect

$\mathrm{Ha}$ : Model mengikuti random effect

4. Uji Asumsi Klasik

Diperlukan Uji Asumsi Klasik apabila model regresi yang digunakan dalam bentuk Common Effects Model atau Fixed Effects Model. Sebaliknya apabila persamaan regresi lebih cocok menggunakan Random Effects Model maka tidak perlu dilakukan uji asumsi klasik. Uji Asumsi Klasik terdiri dari uji Linieritas, Autokorelasi, Multikolineritas, Normalitas, dan Heteroskedastisitas. Walaupun demikian tidak semua uji dilakukan dalam regresi data panel, hanya uji Multikolineritas dan Heteroskedastisitas saja yang diperlukan.

5. Uji Hipotesis

Terdapat tiga jenis uji hipotesis yaitu sebagai berikut:

a. Uji $F$

Adapun hipotesis dalam uji $\mathrm{F}$ adalah sebagai berikut:

Berdasarkan perbandingan F-statistic dengan $\mathrm{F}$ tabel

$\mathrm{HO}$ : Jika nilai F-statistic < F Tabel

$\mathrm{Ha}$ : Jika nilai F-statistic $>\mathrm{F}$ table Berdasarkan Probabilitas

H0 : Jika nilai prob (F-statistic) $>\alpha 0,05$

$\mathrm{Ha}:$ Jika nilai prob (F-statistic) $<\alpha 0,05$ 
b. Uji Koefisien Determinasi

Nilai R-squared berada antara 0 sampai 1 dengan penjelasan sebagai berikut:

i. $\quad$ Nilai R-squared harus berkisar 0 sampai 1

ii. Jika nilai R-squared sama dengan 1, berarti naik atau turunnya variabel terikat $(Y) 100 \%$ dipengaruhi oleh variabel bebas $(X)$

iii. Jika nilai $\mathrm{R}$-squared sama dengan 0 , berarti tidak ada hubungan sama sekali antara variabel independen dengan variabel dependen.

c. Uji T

Hipotesis dalam uji T adalah sebagai berikut:

Berdasarkan perbandingan T-statistic dengan Ttabel

$\mathrm{HO}$ : Jika nilai T-statistic $<\mathrm{T}$ Tabel

$\mathrm{Ha}$ : Jika nilai T-statistic $>\mathrm{T}$ tabel

Berdasarkan Probabilitas

$\mathrm{HO}$ : Jika nilai prob (T-statistic) $>\alpha 0,05$

$\mathrm{Ha}$ : Jika nilai prob (T-statistic) $<\alpha \quad 0,05$

6. Analisis Regresi Data Panel

Regresi data panel adalah gabungan antara data cross section (data beberapa perusahaan) dan data time series (data yang dihimpun lebih dari satu tahun), dimana unit cross section yang sama diukur pada waktu yang berbeda. Maka dengan kata lain data panel merupakan data dari beberapa perusahaan (sampel) yang diamati dalam beberapa kurun waktu tertentu.

\section{HASIL}

\section{Analisis Statistik Deskriptif}

\begin{tabular}{|l|c|c|c|c|c|c|}
\hline & CONACC & DR & SIZE & IM & LEV & ROA \\
\hline Mean & 0.298567 & 1.404733 & 12.67783 & 4.538767 & 0.448633 & 0.061767 \\
\hline Median & 0.230000 & 0.918500 & 12.67200 & 3.561000 & 0.478500 & 0.057000 \\
\hline Maximum & 1.375000 & 7.036000 & 14.31400 & 10.32800 & 0.876000 & 0.169000 \\
\hline Minimum & 0.033000 & 0.081000 & 11.59200 & 0.914000 & 0.075000 & 0.002000 \\
\hline Std. Dev. & 0.276300 & 1.743665 & 0.775150 & 3.080006 & 0.234812 & 0.043659 \\
\hline Skewness & 2.148633 & 2.254908 & 0.467570 & 0.481341 & 0.072318 & 0.858787 \\
\hline Kurtosis & 8.782393 & 7.606502 & 2.618172 & 1.773210 & 2.060126 & 3.187009 \\
\hline & & & & & & \\
\hline Jarque-Bera & 64.87820 & 51.94786 & 1.275347 & 3.039712 & 1.130354 & 3.731288 \\
\hline Probability & 0.000000 & 0.000000 & 0.528521 & 0.218743 & 0.568260 & 0.154796 \\
\hline & & & & & & \\
\hline Sum & 8.957000 & 42.14200 & 380.3350 & 136.1630 & 13.45900 & 1.853000 \\
\hline Sum Sq. Dev. & 2.213903 & 88.17061 & 17.42489 & 275.1066 & 1.598969 & 0.055277 \\
\hline & \multicolumn{7}{|c|}{} & & & & \\
\hline Observations & 30 & 30 & 30 & 30 & 30 & 30 \\
\hline
\end{tabular}

Sumber: Data diolah 
Pada tabel di atas, dapat dijelaskan bahwa jumlah data (observations) yang digunakan dalam penelitian ini sebanyak 30 data.

Nilai Mean terbesar dialami oleh variabel sebesar SIZE 12.67783, sementara variabel ROA memiliki nilai mean terkecil yaitu sebesar 0.061767.

Median terbesar dialami oleh variabel SIZE yaitu sebesar 12.67200, sementara variabel ROA memiliki median terkecil yaitu sebesaar 0.057000 .

Maximum terbesar dialami oleh variabel SIZE yaitu sebesar 14.31400 sementara variable ROA memiliki maximum terkecil yaitu sebesar 0.169000 .

Minimum terbesar dialami oleh variabel SIZE yaitu sebesar 11.59200, sementara variabel ROA memiliki minimum terkecil yaitu sebesar 0.002000 .

Nilai standar deviasi terbesar dialami oleh variabel Intentitas Modal yaitu sebesar 3.080006, sementara variabel ROA mempunyai nilai standar deviasi yang paling rendah yaitu sebesar 0.043659 .

Positive skewness menunjukkan bahwa distribusi datanya memiliki ekor panjang di sisi kanan dan negative skewness memiliki ekor panjang di kiri.Untuk Variabel CONACC dan DR memiliki nilai diatas 0 (nol) yang berarti bahwa asimetri distribusi data sekitar mean tidak normal, sedangkan variabel SIZE, IM, LEV dan ROA memiliki nilai sekitar 0 (nol) yang berarti bahwa asimetri distribusi data disekitar mean bersifat normal. Kurtosis suatu data berdistribusi normal adalah 3. Bila kurtosis melebihi 3, maka distribusi data dikatakan leptokurtis terhadap normal. Bila kurtosis kurang dari 3, distribusi datanya datar (platykurtic) dibanding dengan data berdistribusi normal. Untuk variabel CONACC, DR, dan ROA memiliki nilai kurtosis lebih dari 3, sementara variabel SIZE,IM dan ROA memiliki nilai kurtosis kurang dari 3.

Jarque-Bera adalah uji statistik untuk mengetahui apakah data berdistribusi normal. Uji ini mengukur perbedaan skewness dan kurtosis data dan dibandingkan dengan apabila datanya bersifat normal. Dengan $\mathrm{HO}$ pada data berdistribusi normal, uji JaqueBera didistribusi dengan X2 dengan derajat bebas (degree of freedom) sebesar 2. Probability menunjukkan kemungkinan nilai Jarque-Bera melebihi (dalam nilai absolut) nilai terobservasi di bawah hipotesis nol. Nilai probabilitas yang kecil cenderung mengarahkan pada penolakan hipotesis nol distribusi normal. 


\section{Estimasi Model Regresi Data Panel \\ Common Effect Model (CEM)}

Berikut estimasi common effect model sebagai berikut :

Dependent Variable: CONACC

Method: Panel Least Squares

Date: $07 / 05 / 20$ Time: $14: 31$

Sample: 20172018

Periods included: 2

Cross-sections included: 15

Total panel (balanced) observations: 30

\begin{tabular}{crrrr}
\hline \hline \multicolumn{1}{c}{ Variable } & Coefficient & Std. Error & t-Statistic & Prob. \\
\hline \hline C & 2.618375 & 0.769388 & 3.403193 & 0.0023 \\
DR & 0.037672 & 0.043486 & 0.866299 & 0.3949 \\
SIZE & -0.170755 & 0.065579 & -2.603816 & 0.0156 \\
IM & 0.010451 & 0.019536 & 0.534974 & 0.5976 \\
LEV & -0.475875 & 0.341055 & -1.395303 & 0.1757 \\
ROA & -0.677768 & 1.372007 & -0.493997 & 0.6258 \\
\hline \hline & & & & 0.298567 \\
R-squared & 0.456955 & Mean dependentyar & 0.276300 \\
Adjusted R-squared & 0.343820 & S.D. dependentyar & 0.020874 \\
S.E. of regression & 0.223816 & Akaike info criterion & 0.301114 \\
Sum squared resid & 1.202249 & Schwarz criterion & 0.110525 \\
Log likelihood & 5.686889 & Hannan-Quinn criter. & 0.693859 \\
F-statistic & 4.039044 & Durbin-Watson stat & \\
Rrob(F-statistic) & 0.008419 & & & \\
\hline \hline
\end{tabular}

Sumber : Data Diolah

Fixed Effect Model (FEM)

Berikut estimasi Fixed effect model sebagai berikut :

\begin{tabular}{|c|c|c|c|c|}
\hline \multicolumn{5}{|c|}{$\begin{array}{l}\text { Dependent Variable: CONACC } \\
\text { Method: Panel Least Squares } \\
\text { Date: 07/05/20 Time: } 14: 32 \\
\text { Sample: } 20172018 \\
\text { Periods included: } 2 \\
\text { Cross-sections included: } 15 \\
\text { Total panel (balanced) observations: } 30\end{array}$} \\
\hline Variable & Coefficient & Std. Error & t-Statistic & Prob. \\
\hline $\mathrm{C}$ & 8.387568 & 7.454140 & 1.125223 & 0.2868 \\
\hline DR & 0.660097 & 0.343635 & 1.920928 & 0.0837 \\
\hline SIZE & -0.644726 & 0.587826 & -1.096796 & 0.2984 \\
\hline $\mathrm{IM}$ & 0.017656 & 0.112486 & 0.156958 & 0.8784 \\
\hline LEV & -2.016471 & 1.124626 & -1.793015 & 0.1032 \\
\hline ROA & -0.291682 & 1.401166 & -0.208171 & 0.8393 \\
\hline \multicolumn{5}{|c|}{ Effects Specification } \\
\hline \multicolumn{5}{|c|}{ Cross-section fixed (dummy variables) } \\
\hline R-squared & 0.942071 & & 0.298567 \\
\hline Adjusted R-squared & 0.832005 & & S.D. dependentyar & 0.276300 \\
\hline S.E. of regression & 0.113247 & \multicolumn{2}{|c|}{ Akaike info criterion } & -1.283761 \\
\hline Sum squared resid & 0.128250 & \multicolumn{2}{|c|}{ Schwarz criterion } & -0.349630 \\
\hline Log likelihood & 39.25642 & \multicolumn{2}{|c|}{ Hannan-Quinn criter. } & -0.984925 \\
\hline F-statistic & 8.559167 & \multicolumn{2}{|c|}{ Durbin-Watson stat } & 3.750000 \\
\hline Prob(F-statistic) & 0.000693 & & & \\
\hline
\end{tabular}


Dependent Variable: CONACC

Method: Panel EGLS (Cross-section random effects)

Date: 07/05/20 Time: $14: 34$

Sample: 20172018

Periods included: 2

Cross-sections included: 15

Total panel (balanced) observations: 30

Swamy and Areca estimator of component variances

\begin{tabular}{|c|c|c|c|c|}
\hline Variable & Coefficient & Std. Error & t-Statistic & Prob. \\
\hline c & 3.139528 & 1.079582 & 2.908097 & 0.0077 \\
\hline DR & 0.038771 & 0.057339 & 0.676161 & 0.5054 \\
\hline SIZE & -0.221312 & 0.087364 & -2.533204 & 0.0183 \\
\hline IM & 0.012348 & 0.023574 & 0.523806 & 0.6052 \\
\hline LEV & -0.269746 & 0.343937 & -0.784290 & 0.4405 \\
\hline ROA & -0.399885 & 1.146180 & -0.348885 & 0.7302 \\
\hline \multicolumn{5}{|c|}{ Effects Specification } \\
\hline & & & S.D. & Rho \\
\hline Cross-section random & & & 0.218455 & 0.7882 \\
\hline Idiosyncraticrandom & & & 0.113247 & 0.2118 \\
\hline \multicolumn{5}{|c|}{ Weighted Statistics } \\
\hline R-squared & 0.287991 & \multirow{5}{*}{\multicolumn{2}{|c|}{$\begin{array}{l}\text { Mean dependentyar } \\
\text { S.D. dependent yar } \\
\text { Sum squared resid } \\
\text { Durbin-Watson stat }\end{array}$}} & 0.102758 \\
\hline Adjusted R-squared & 0.139656 & & & 0.125641 \\
\hline S.E. of regression & 0.116538 & & & 0.325946 \\
\hline F-statistic & 1.941492 & & & 2.311988 \\
\hline Prob(F-statistic) & 0.124520 & & & \\
\hline \multicolumn{5}{|c|}{ Unweighted Statistics } \\
\hline $\begin{array}{l}\text { R-squared } \\
\text { Sum squared resid }\end{array}$ & $\begin{array}{l}0.432614 \\
1.256137\end{array}$ & $\begin{array}{l}\text { Mean depenc } \\
\text { Durbin-Wats }\end{array}$ & $\begin{array}{l}\text { tyar } \\
\text { stat }\end{array}$ & $\begin{array}{l}0.298567 \\
0.599920\end{array}$ \\
\hline
\end{tabular}

Sumber : Data Diolah

\section{Pemilihan Model Regresi Data Panel}

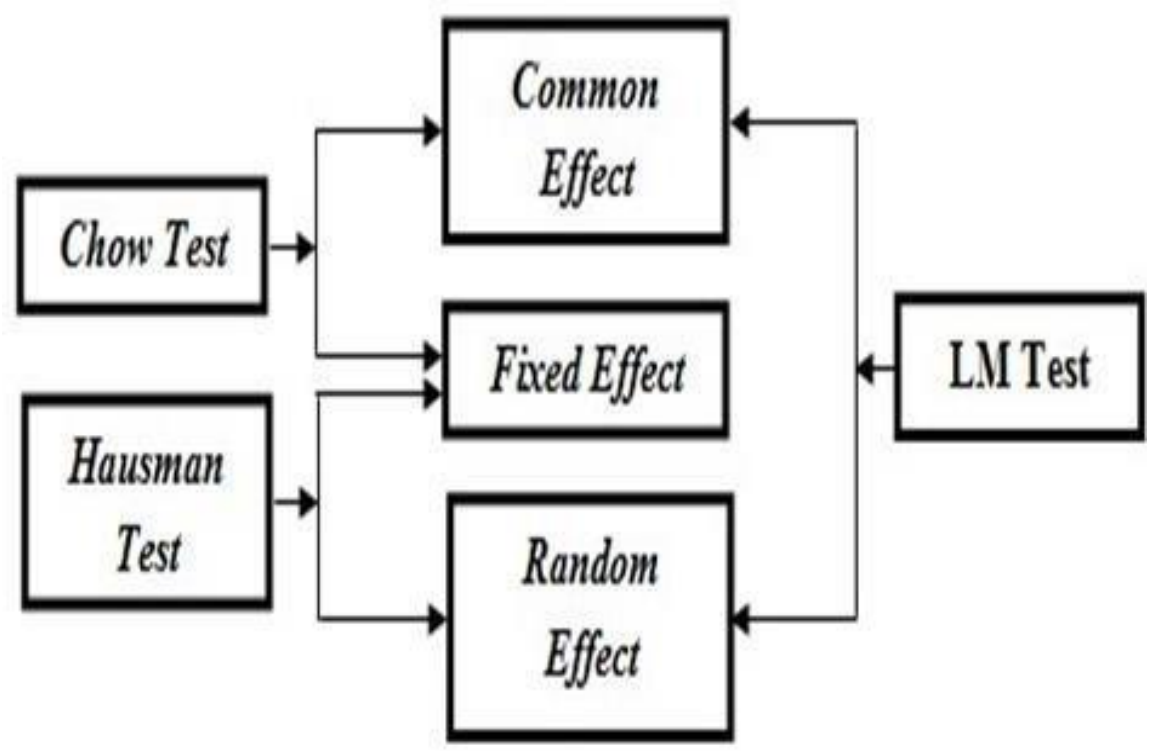

Skema Pemilihan Model Regresi Data Panel 


\section{Uji Chow}

\begin{tabular}{lrrr}
$\begin{array}{l}\text { Redundant Fixed Effects Tests } \\
\text { Equation: EQ01 } \\
\text { Test cross-section fixed effects }\end{array}$ & & & \\
\hline \hline Effects Test & Statistic & d.f. & Prob. \\
\hline \hline Cross-section F & 5.981622 & $(14,10)$ & 0.0037 \\
Cross-section Chi-square & 67.139065 & 14 & 0.0000 \\
\hline \hline
\end{tabular}

Sumber : Data diolah

Berdasarkan hasil perhitungan diatas nilai Probabilitas Cross-section $F$ dan Crosssection chi-square $<0,05$, maka dapat disimpulkan bahwa Fixed Effect Model (FEM) lebih layak digunakan dibandingkan Common Effect Model (CEM).

\section{UjiHausman}

\begin{tabular}{|c|c|c|c|}
\hline Test Summary & $\begin{array}{l}\text { Chi-Sq. } \\
\text { Statistic }\end{array}$ & Chi-Sq. d.f. & Prob. \\
\hline Cross-section random & 6.414875 & 5 & 0.2679 \\
\hline
\end{tabular}

Sumber :Data diolah

Berdasarkan hasil perhitungan diatas nilai Probabilitas Crosss-section random > 0,05, maka dapat disimpulkan bahwa Random Effect Model (REM) lebih layak digunakan dibandingkan Fixed Effect Model (FEM).

\section{Uji lagrange Multiplier}

Lagrange Multiplier Tests for Random Effects Null hypotheses: No effects

Alternative hypotheses: Two-sided (Breusch-Pagan) and one-sided (all others) alternatives

\begin{tabular}{lccc}
\hline & \multicolumn{3}{c}{ Test Hypothesis } \\
& Cross-section & Time & Both \\
\hline Breusch-Pa14gan & $\begin{array}{l}5.952397 \\
(0.0147)\end{array}$ & $\begin{array}{l}0.084654 \\
(0.7711)\end{array}$ & $\begin{array}{l}\text { 6.037051 } \\
(0.0140)\end{array}$
\end{tabular}

Berdasarkan hasil perhitungan nilai Probabilitas Cross-section BreuschPagan < 0,05, maka dapatdisimpulkan bahwa Random Effect Model (REM) lebih layak digunakan dibandingkan Common Effect Model (CEM).

\section{Kesimpulan Model}

No Metode

1. Uji Chow

2. Uji Hausman
Pengujian

CEM vs FEM

REM vs FEM
Hasil

FEM

FEM 
Berdasarkan hasil perhitungan nilai Probabilitas Cross-section BreuschPagan < 0,05, maka dapatdisimpulkan bahwa Random Effect Model (REM) lebih layak digunakan dibandingkan Common Effect Model (CEM).

\section{Uji Hipotesis}

Uji F

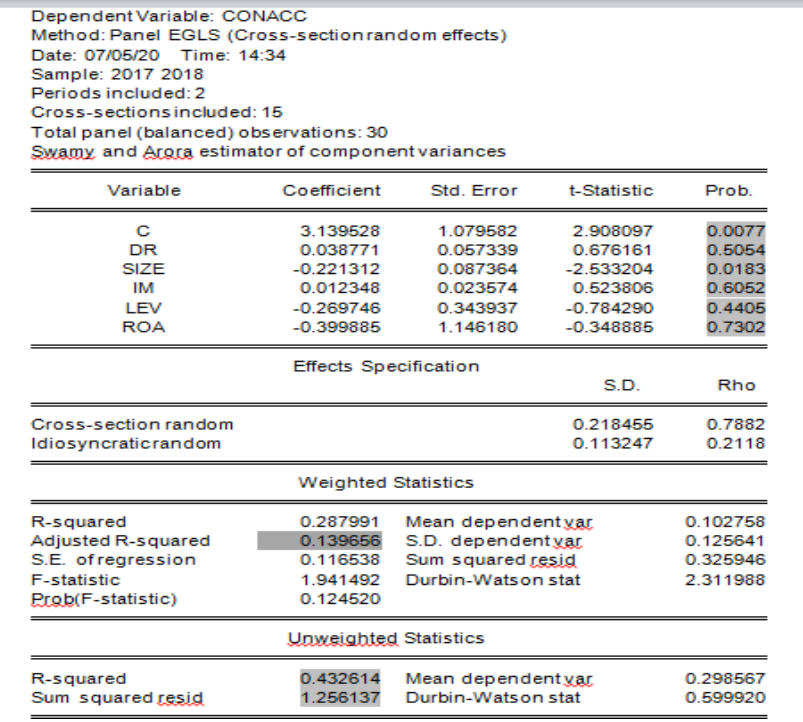

Berdasarkan hasil tabel Random Effect Model yang ditampilkan pada tabel diatas menunjukkan bahwa nilai Fstatistic sebesar 1.941492, sementara $F$ Tabel dengan tingkat $\alpha=5 \%$, df1 (k-1)

$=5$ dan df2 $(n-k)=26$ didapat nilai $F$ Tabel sebesar 2.620694. Dengan demikian F-statistic (1.941492) > F

Tabel (2.620694) dan nilai Prob(Fstatistic) $0.124520<0,05$ maka

dapat disimpulkan bahwa Ha diterima, yang artinya variabel - variabel independen dalam penelitian ini yang

terdiri dari Leverage, Ukuran Perusahaan, Intentitas Modal, Debt Covenant, Profitabilitas secara bersama-sama memiliki pengaruh terhadap Konservatisme Akutansi

\section{Uji Koefisien Determinasi (R-Squared)}

Berdasarkan hasil tabel RandomEffect

Model yang ditampilkan pada tabel diatas menunjukkan Berdasarkan tabel di atas, menunjukkan bahwa nilai Adjusted R-squared sebesar 0.139656, artinya bahwa variasi perubahan naik turunnya Konversatisme Akutansi dapat dijelaskan oleh Leverage, Ukuran Perusahaan, Intentitas Modal Debt Covenant,dan Profitablitas Penjualan sebesar 13.96 persen, sementara sisanya yaitu sebesar 86.04 persen dijelaskan oleh variabel variabel lain yang tidak diteliti dalamVpenelitian ini. 


\section{Uji T}

Dari hasil yang ditampilkan pada tabel diatas menunjukan bahwa hasil uji $t$ Leverage, Ukuran Perusahaan, Inetitas Modal, Debt Covenant dan Profitabilitas terhadap Konservatisme Akuntansi adalah sebagai berikut:

Nilai t-statistic Leverager (DR) sebesar 0.676162, sementara t Tabel dengan tingkat $\alpha=5 \%$, df $(n-k)=26$ didapat nilai $t$ Tabel sebesar 2,055529. Dengan demikian $t-$ statistic Leverage $(0.676162)<t$ Tabel (2.055529) dan nilai Prob. 0.5054> 0,05 maka dapat disimpulkan bahwa variabel Leverage dalam penelitian ini tidak memiliki pengaruh terhadap Konservatisme Akuntansi. Dengan demikian, $\mathrm{H} 1$ dalam penelitian ini diterima.

b.Nilai t-statistic Ukuran Perusahaan (SIZE) sebesar - 2.533204. Sementara $t$ Tabel dengan tingkat $\alpha=5 \%$, df $(n-k)=26$ didapat nilai $t$ Tabel sebesar 2,055529. Dengan demikian t-statistic SIZE (- 2.533204) >t Tabel $(2,055529)$ dan nilai Prob 0,0183 < 0,05 maka dapat disimpulkan bahwa variabel Ukuran Perusahaan dalam penelitian ini memiliki pengaruh terhadap Konservatisme Akuntansi.

Dengan demikian, $\mathrm{H} 2$ dalam penelitian ini diterima.

Nilai t-statistic Intentintas Modal (IM) sebesar 0.523806. Sementara t Tabel dengan tingkat $\alpha=5 \%$, df ( $n-$

$\mathrm{k})=26$ didapat nilai $\mathrm{t}$ Tabel sebesar 2,055529. Dengan demikian $\mathrm{t}-$ statistic Intentitas Modal $(0.523806)<t$ Tabel $(2,055529)$ dan nilai Prob. 0,6052 > 0,05 maka dapat disimpulkan bahwa variabel Intentitas Modal dalam penelitian ini tidak memiliki pengaruh terhadap Konservatisme Akuntansi. Dengan demikian, $\mathrm{H} 3$ dalam penelitian ini ditolak.

Nilai t-statistic Debt Covenant sebesar -0,784290. Sementara t Tabel dengan tingkat $\alpha=5 \%$, df $(n-k)=26$ didapat nilai $t$ Tabel sebesar 2,055529. Dengan demikian $t-$ statistic Likuiditas $(-0,784290)<t$ Tabel (2.055529) dan nilai Prob. 0,4405 > 0,05 maka dapat disimpulkan bahwa variabel Debt Covenant dalam penelitian ini tidak memiliki pengaruh terhadap Konservatisme Akuntansi. Dengan demikian, H4 dalam penelitian ini ditolak.

Nilai t-statistic Profitabilitas (ROA) sebesar 0.348885 . Sementara t Tabel dengan tingkat $\alpha=5 \%$, df $(n-k)=26$ didapat nilai $t$ Tabel sebesar 2,055529. Dengan demikian t- statistic Profitabilitas $(0.348885)<\mathrm{t}$ Tabel $(2,055529)$ dan nilai Prob. 0,7302 > 0,05 maka dapat disimpulkan bahwa variabel Leverage dalam penelitian ini tidak memiliki pengaruh terhadap Konservatisme Akuntansi. Dengan demikian, H5 dalam penelitian ini ditolak.

Analisa Model Regresi Data Panel Hasil persamaan regresi yang diperoleh adalah :

$\mathrm{Y}=3.139528+0.038771-$
$0.2211312+0.012348-0.269746-$
$0.3998885+£$


Nilai konstanta $=3.139528$ bernilai positif. Hal ini mengindikasikan bahwa jika variabel Leverage, Ukuran Perusahaan, Intentitas Modal, Debt Covenant, Profitabilitas sama dengan nol (0) atau konstan, maka variabel Konservatisme Akuntansi akan meningkat sebesar 3.139528.

Nilai koefisien regresi variabel Leverage positif sebesar - 0,038771. Hal ini berarti apabila Leverage mengalami penurunan sebesar satu satuan, maka diikuti peningkatan koefisien Konservatisme Akuntansi sebesar -0,038771, dengan asumsi variabel lainnya konstan.

Nilai koefisien regresi variabel Ukuran Perusahaan negative sebesar - 0.2211312 arinya apabila Ukuran Perusahaan mengalami penurunan sebesar satu satuan, maka diikuti peningkatan koefisien konservatisme akuntansi sebesar - 0.2211312, dengan asumsi variabel lainnya konstan.

Nilai koefisien regresi variabel Inntitas Modal negative sebesar 0.2697460. Hal ini berarti apabila Intentitas Modal mengalami penurunan sebesar satu satuan, maka diikuti peningkatan koefisien konservatisme akuntansi sebesar - 0.2697460 , dengan asumsi variabel lainnya konstan. Nilai koefisien regresi variabel Debt Covenant negative sebesar 0,2697460. Hal ini berarti apabila Debt Covenant mengalami penurunan sebesar satu satuan, maka diikuti peningkatan koefisien konservatisme akuntansi sebesar - 0,2697460, dengan asumsi variabel lainnyya konstan.

Nilai koefisien regresi variabel Profitabilitas negatif sebesar 0.399885. Hal ini berarti apabila Profitabilitas mengalami peningkatan sebesar satu satuan, maka akan diikuti peningkatan koefisien konservatisme akuntansi sebesar 0.399885 dengan asumsi variabel lainnya konstan.

\section{KESIMPULAN}

Berdasarkan uji t (parsial) variabel Leverage dalam penelitian ini tidak memiliki pengaruh terhadap Konservatisme Akuntansi. Hal ini menunjukan jika perusahaan mempunyai hutang yang tinggi atau rendah tidak akan menjadikan perusahaan semakin konservatif karena kemungkinan perusahaan akan selalu menggunakan prinsip konservatisme untuk menghadapi keadaan yang tidak pasti sehingga tinggi rendahnya tingkat hutang tidak akan mempengaruhi konservatisme. Hasilini bertentangan dengan peneliti Lo (2005).

Berdasarkan uji t (parsial) variabel Ukuran Perusahaan dalam penelitian ini memiliki pengaruh terhadap Konservatisme Akuntansi. Semakin besar Ukuran Perusahaan maka semakin konservatif perusahan tersebut. Hasil penelitian ini mendukung penelitian Sari dan Adhariani (2009) bahwa ukuran perusahaan berpengaruh signifikan terhadap tingkat konservatisme akuntansi.

Berdasarkan uji t (parsial) variabel Ukuran Perusahaan dalam penelitian ini memiliki pengaruh terhadap Konservatisme Akuntansi.

Semakin besar Ukuran Perusahaan maka semakin konservatif perusahan tersebut. Hasil penelitian ini mendukung penelitian Sari dan Adhariani 
(2009) bahwa ukuran perusahaan berpengaruh signifikan terhadap tingkat konservatisme akuntansi.

Berdasarkan uji t (parsial) maka dapat disimpulkan bahwa variabel Debt Covenant dalam penelitian ini memiliki pengaruh terhadap Konservatisme Akuntansi. Hal tersebut berarti semakin rendah nilai debt covenant perusahaan maka tingkat konservatifnya semakin meningkat. Hasil penilitian ini tidak sejalan dengan penilitian yang dilakukan oleh Susanto dan Ramadhani (2016), Tosi dan Paidar (2015) yang menyatakan Debt Covenant tidak memiliki pengaruh terhadap konservatisme akuntansi.

Berdasarkan uji t (parsial) variabel Profitabilitas dalam penelitian ini tidak memiliki pengaruh terhadap Konservatisme akuntansi. Besar kecilnya profitabilitas tidak akan mempengaruhi peringkat obligasi perusahaan di masa mendatang. Hasil penelitian ini sejalan dengan penelitian Susilowati dan Sumarto (2010) serta Almilia dan Devi (2007

\section{DAFTAR PUSTAKA}

Sari, D. N., Yusraliani, \& L, A. (2014). Pengaruh Struktur Kepemilikan Institutional, Struktur Kepemilikan Manajerial, Struktur Kepemilikan Publik, Debt Covenant dan Growth Opportunities terhadap Konservatisme Akuntansi. Jurnal Online Mahasiswa Fakultas Ekonomi Universitas Riau, 1(2), 1-15.

Iskandar, O. R., \& Sparta, S. (2019). Pengaruh Debt Covenant, dan Political Cost Terhadap Konservatisme Akuntansi. Equity, 22(1), 47. https://doi.org/10.34209/e qu.v22i1.896

Noviantari, N., \& Ratnadi, N. (2015). Pengaruh Financial Distress, Ukuran Perusahaan, Dan Leverage Pada Konservatisme Akuntansi. EJurnal Akuntansi, 11(3), 646-660.

Zuhriyah, E. A. (2016). Konvergensi IFRS, Leverage, Financial Distress, Litigation Dalam Kaitannya dengan Konservatisme Akuntansi.

Fakultas Ekonomi - Universitas Negeri Surabaya, 204-219.

Lestari Dewi, N., \& Suryanawa, (2014). Pengaruh Struktur Kepemilikan Manajerial, Leverage, Dan Financial Distress Terhadap

Konservatisme Akuntansi. E-Jurnal Akuntansi, 7(1), 223-234.

Abdurrahman, M. A., \& Ermawati, W. J. (2019). Pengaruh Leverage, Financial Distress dan Profitabilitas terhadap Konservatisme Akuntansi pada Perusahaan Pertambangan di Indonesia Tahun 2013-2017. Jurnal Manajemen Dan Organisasi, 9(3), 164-173. https://doi.org/10.29244/jmo.v9i3.28 227

Utama, E. P., \& Titik, D. F. (2018). Pengaruh Leverage, Ukuran Perusahaan, Kepemilikan Manajerial Dan Profitabilitas Terhadap 
Konservatisme Akuntansi. E-Proceeding of Management, $5(1), 720$.

Susilo, T., \& Aghni, J. (2017). Analisis Pengaruh Kepemilikan Institusional, Debt Covenant, Growth Opportunities, dan Profitabilitas Terhadap Konservatisme Akuntansi. Media Riset Akuntansi, 5(2), Hal. 4-21.

Handayanu, R. S., \& Agustono, D. R. (2009). Pengaruh Ukuran Perusahaan Terhadap. Jurnal Bisnis Dan Akuntansi, 11(1), 33-56.

Purnama, H. W., \& Daljono. (2013). Pengaruh Ukuran Perusahaan, Rasio Leverage, Intensitas Modal, dan Likuiditas Perusahaan Terhadap Konservatisme Perusahaan. Diponegoro Journal of Accounting, 2(3), 1-11. http://ejournal-

s1.undip.ac.id/index.php/accounting

Suharni, S., Wildaniyati, A., \& Andreana, D. (2019). Pengaruh Jumlah Dewan Komisaris, Leverage, Profitabilitas, Intensitas Modal, Cash Flow, Dan Ukuran Perusahaan Terhadap Konservatisme (Studi Empiris Pada Perusahaan Manufaktur Yang Terdaftar Di Bursa Efek Indonesia Tahun 2012-2017). JURNAL EKOMAKS: Jurnal Ilmu Ekonomi, Manajemen, Dan Akuntansi, 8(1), 17-24. https://doi.org/10.33319/j eko.v8i1.30

Exchane, S. (2019). Advance : Jurnal Akuntansi Vol 6, No 1 ( 2019 ); July ISSN: 2337- 5221 ( cetak ) P3M STIE AUB Surakarta Advance: Jurnal Akuntansi ISSN : 2337-5221 ( cetak ) P3M STIE AUB Surakarta. 6(1), 78-94. 